\title{
Variation of Physical and Chemical Properties of Soils under Different Cropping Systems in the Watershed of Kpocomey, Southern Benin
}

\author{
Alladassi Félix Kouelo ${ }^{*}{ }^{\circledR}$, Alohoutade Finagnon Mathieu1, Avakoudjo Julien², \\ Akplo Tobi Moriaque', Agodo Lambert ${ }^{3}$, Agonvinon Mahugnon Socrate ${ }^{1}$, \\ Houngnandan Pascal' ${ }^{1}$, Azontonde Hessou Anastase ${ }^{4}$, Amadji Guillaume Lucien ${ }^{5}$, Saïdou Aliou ${ }^{6}$ \\ ${ }^{1}$ Laboratory of Soil Microbiology and Microbial Ecology, Faculty of Agronomic Sciences of University of Abomey-Calavi, \\ Abomey-Calavi, Benin \\ ${ }^{2}$ Laboratory of Applied Ecology, Faculty of Agronomic Sciences of University of Abomey-Calavi, Abomey-Calavi, Benin \\ ${ }^{3}$ Laboratory of Research in Population and Development Sciences, University of Parakou, Parakou, Benin \\ ${ }^{4}$ Soil, Water and Environmental Sciences Laboratory, National Institute of Agricultural Research of Benin, Abomey-Calavi, Benin \\ ${ }^{5}$ Research Unit of Eco-Pedology, Laboratory of Soil Sciences, Faculty of Agronomic Sciences, University of Abomey-Calavi, \\ Abomey-Calavi, Benin \\ ${ }^{6}$ Integrated Soil and Crop Management Research Unit, Laboratory of Soil Sciences, Faculty of Agronomic Sciences, University of \\ Abomey-Calavi, Abomey-Calavi, Benin \\ Email: ^felix.kouelo@gmail.com
}

How to cite this paper: Kouelo, A.F., Mathieu, A.F., Julien, A., Moriaque, A.T., Lambert, A., Socrate, A.M., Pascal, H., Anastase, A.H., Lucien, A.G. and Aliou, S. (2020) Variation of Physical and Chemical Properties of Soils under Different Cropping Systems in the Watershed of Kpocomey, Southern Benin. Open Journal of Soil Science, 10, 501-517.

https://doi.org/10.4236/ojss.2020.1011026

Received: October 14, 2020

Accepted: November 27, 2020

Published: November 30, 2020

Copyright (c) 2020 by author(s) and Scientific Research Publishing Inc. This work is licensed under the Creative Commons Attribution International License (CC BY 4.0).

http://creativecommons.org/licenses/by/4.0/

\begin{abstract}
Soils degradation is one of the constraints in food security achievement in Benin. This study aimed at assessing the effect of cropping systems and slope on soil physical and chemical properties in the watershed of Kpacomey located in the Aplahoué district. Soil samples were collected from three parallel transects along the slope. Sampling was carried out under different treatments combining cropping systems (Maize-Cassava, pure Palm grove, Palm grove-Maize-Cassava and Teak Plantation) along with slope levels (low slope, medium slope and high slope degree). The impact of cropping systems and slope on soil properties was assessed by determining the physical and chemical parameters. The cropping systems significantly $(\mathrm{p}<0.05)$ influenced soil bulk density, root biomass, soil acidity and soil organic matter. The lowest soil bulk density $\left(1.38 \mathrm{~g} / \mathrm{cm}^{3}\right)$ was recorded under the Palm grove-Maize-Cassava cropping system while the highest $\left(1.47 \mathrm{~g} / \mathrm{cm}^{3}\right)$ was obtained with pure Palm grove cropping system. Root biomass was more abundant $(0.28 \%)$ with the pure Palm grove cropping system. However, root biomass was significantly $(\mathrm{p}<0.05)$ influenced by slope. Soil crusting resulted in no significant influence ( $p>0.05)$ on the effect of cropping systems and slope. Moreover, cropping systems resulted in significant effects $(p<0.05)$. Soil organic matter and
\end{abstract}


soil-assimilated phosphorus content were significantly influenced by the effect of the slope. These findings indicated that cropping systems and slope are significant drivers in soil degradation in the Kpacomey watershed and bringing out cropping systems that best aim at soil conservation.

\section{Keywords}

Cropping Systems, Soil Organic Matter, Soil Degradation, Benin

\section{Introduction}

The world is caught in a growing circle with a growing population that is insisting on food that it cannot obtain by abusing the land and depleting its forests and soil [1]. Agricultural production needs to be increased by $60 \%$ globally and by almost $100 \%$ in developing countries alone to meet human food demand [2]. Many countries where agricultural capital per worker and public investment in agriculture have stagnated are the epicenters of global poverty and hunger [3]. In these countries, agriculture is almost abandoned to farmers without clear regulation of natural resource exploitation [4]. Indeed, increasing rainfed agricultural production and maintaining the productive capacities of agro-systems are the major challenges for smallholder farmers in Africa [5]. In Sub-Saharan, the conjunction of phenomena such as poverty, population growth, worsening climatic conditions, and increasing anthropization has resulted in a strong degradation of non-renewable or hardly renewable natural resources, especially forests, soils, and water [6] [7]. In addition, population growth has led to a lot of human pressure on renewable natural resources [8]. Thus, this human pressure has led to the expansion of urban spaces at the expense of arable land and the loss of much fertile land [6]. As a result, agricultural land and even marginal land with low fertility are under permanent cultivation [8], causing the depletion of soil organic matter and nutrients, collapse of soil structure, loss of productivity of arable land, soil erosion and land abandonment.

In Benin, the growth of the rural population on the one hand and the response to the over-increasing food demand from urban areas on the other hand have led to a strong pressure on the land [9]. Despite the land pressure in southern Benin, agricultural practices have not changed much to significantly improve the productivity and to sustainably feed the ever-growing population [10]. Agriculture in Benin is becoming more and more mining and will cause in the short and medium term an irreversible degradation of land and ecosystems. In contrast to developed countries and highly urbanized countries, the major factor responsible for soil degradation in Benin has so far been the non-sustainable farming [11]. In the central region of Benin, studies applying the Revised Universal Soil Loss Equation (RUSLE) in combination with Geographic Information System and remote sensing have clearly shown the susceptibility of "Terre de barre" 
soils to water erosion [12]. In fact, land degradation is accelerating due to overgrazing, over-cultivation of crops, poor irrigation methods, deforestation as well as climate changes [6]. According to [9], soil degradation is a considerable problem in Benin, due to high rainfall intensities and widespread low-input production systems. Likewise, most of the cropping systems in Benin result in soil degradation [13], making the population more vulnerable to food insecurity as the sustainability of production systems and crop yields are compromised [4].

Continued soil degradation caused by non-sustainable farming systems, erosion, declining organic matter, nutrient depletion, etc., may cause irreparable damage to environment and to Benin's agriculture [13]. In this context of increasing depletion of arable land, the restoration of degraded land and the development of land use systems capable of preserving ecosystems become imperative. This study aimed at assessing the effect of cropping systems and slope on soil health in the Kpacomey watershed located in the district of Aplahoue in Southern Benin.

\section{Material and Methods}

\subsection{Experimental Site Description}

The watershed of Kpacomey is located in the district of Aplahoué. With a surface area of $82,585 \mathrm{~km}^{2}$, the Kpacomey watershed is between $6^{\circ} 48^{\prime} 00^{\prime \prime} \mathrm{N}-7^{\circ} 010^{\prime \prime} \mathrm{N}$ and $1^{\circ} 39^{\prime} 00^{\prime \prime E}-1^{\circ} 42^{\prime} 0^{\prime \prime E ~(F i g u r e ~ 1) . ~ T h e ~ w a t e r s h e d ~ i s ~ c h a r a c t e r i z e d ~ b y ~ a ~}$ four-season sub-equatorial climate (two dry and two wet seasons) and annual rainfall varies from 900 to $1100 \mathrm{~mm}$ /year. Being part of the plateau of Adja, thewatershed of Kpacomey has an average altitude of $80 \mathrm{~m}$ and slopes slightly southward where it connects sensitively to the median "Tchi" depression. Ferrallitic soils with low desaturation in (B) are the dominant soils of the Kpacomey watershed which are subject to strong agro-fertilization pressure due to their degradation and nutrient depletion. Moreover, this degradation is due to the topography and the different cropping systems that are adopted and practiced on this type of soil. The vegetation cover of the Kpacomey watershed is being reduced more and more to artificial vegetation and is composed of a few forest islands in the form of fetish or sacred forests and Saxicolian forests, but of very small dimensions. The watershed of Kpacomey is drained by a permanent stream called Kpaco.

\subsection{Methodology Approach}

The first factor of this study is "cropping systems" with four modalities: Maize-Cassava system, pure Palm grove system, Palmgrove-Cassava system and Teak Plantation system. The "slope" is the second factor of this study with three modalities: Low Slope, Medium Slope and High Slope. The slope steepness in degrees was measured with a SUUNTO type clinometer at each sampling point on each transect. From these measurements, three classes of slope in degrees were identified: $\angle 5^{\circ} ; 5^{\circ}$ to $10^{\circ}$ and $>10^{\circ}$ and were assigned to the Low Slope, Medium Slope and High Slope modalities. 


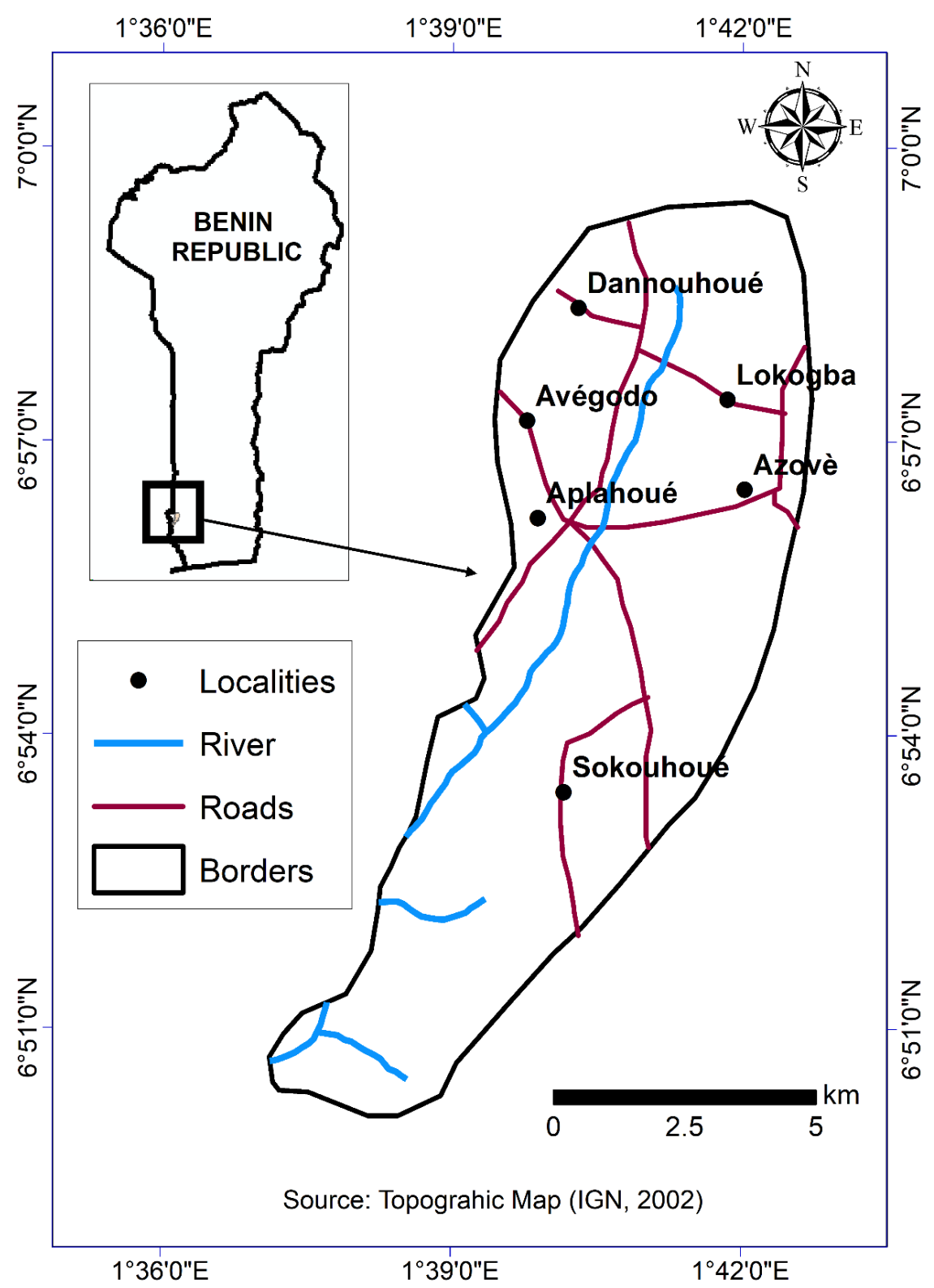

Figure 1. Geographical location of the experimental site: watershed of Kpacomey.

All cropping systems are rainfed. In the Maize-cassava cropping system, cassava is generally planted in association with sown maize (direct sowing after no-tillage soil preparation) about two weeks earlier. After the maize harvest, cassava occupies the field for the rest of its growth cycle. Cassava root harvesting can start from the sixth to the twelfth month after planting depending on the variety. For the Pure Palm Grove cropping system, the palm trees are planted 10 years ago. The teak plantations are around five years-old and are installed for timber production. The effect of cropping systems and slope on the soil degradation in the Kpacomey watershed was assessed using the approach based on the physical and chemical characteristics of the soil. To achieve this goal, soil samples were collected along three parallel transects in the slope direction (Figure 2). 


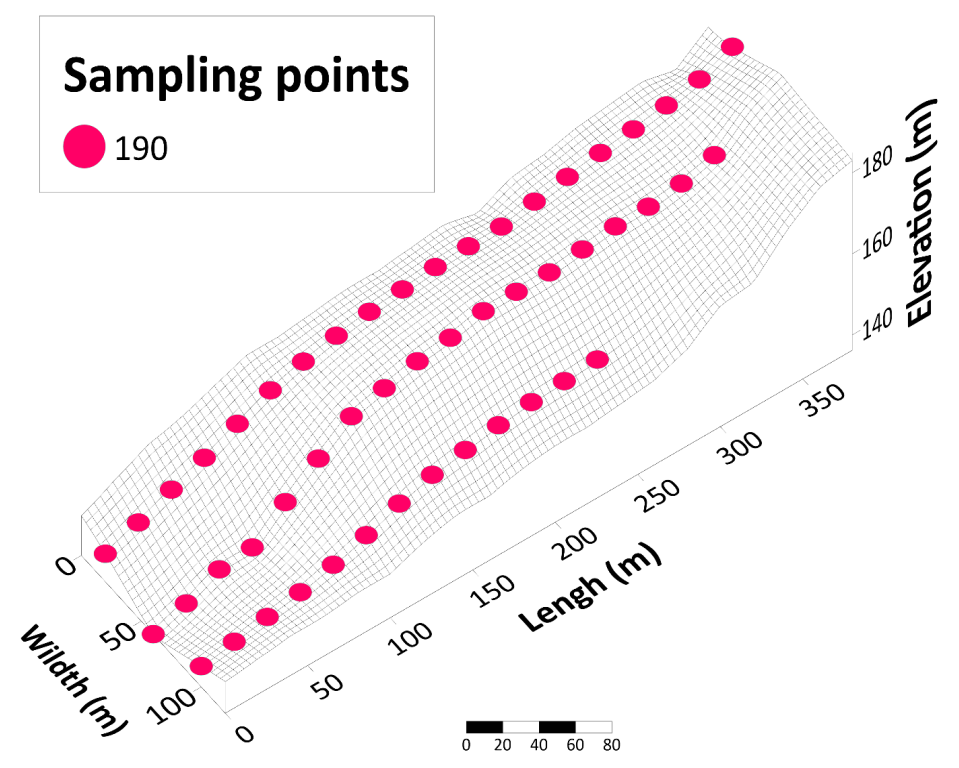

Figure 2. Sampling design for collection of soil cores (Multiple transects).

Transects are 30 meters from each other. On each transect, soil samples were taken every 20 meters using a soil sampler in the depth of $30 \mathrm{~cm}$. The number of soil samples that were collected per transect is a function of the length of the transect and the occupancy of the cropping systems. A total of 51 soil samples were collected: 20 soil samples on transect 1, 18 soil samples on transect 2 and 13 soil samples on transect 3 . The repartition on the number of sampling taken by cropping is as follow: 16 in the Maize-Cassava system, 14 samples in the pure Palm grove system, 11 in the Palm grove-Cassava system and 10 in the Teak Plantation system. As for the slope modalities, 15; 16 and 20 soil samples were taken respectively for Low Slope, Medium Slope and High Slope. The geographic coordinates of all soil sampling points were taken using GPS. A clinometer and a wooden stake were used to take slope measurements. In addition, all soil samples were taken from ferrallitic soils with low desaturation in (B) at the watershed of Kpacomey.

\subsection{Data Collection and Treatment}

After sampling, the soil samples were air dried and sieved at $2 \mathrm{~mm}$ mesh size. The physical and chemical soil analyses were made at the Laboratory of Soil Microbiology and Microbial Ecology (LMSEM) of the Faculty of Agronomic Sciences at the University of Abomey-Calavi. The targeted parameters were soil texture, bulk density, threshing index, root biomass, current and potential soil acidity $\left(\mathrm{pH}_{\mathrm{H} 2 \mathrm{O}}, \mathrm{pH}_{\mathrm{KCl}}\right)$, soil organic matter and available phosphorus. The appropriate analytical method for each parameter was used. Soil texture, actual acidity $\left(\mathrm{pH} \mathrm{H}_{2} \mathrm{O}\right)$ and potential acidity $(\mathrm{pH} \mathrm{KCl})$, soil organic matter content (Organic Carbon $(\%) \times 1.724)$ and available phosphorus were determined respectively by the Robinson pipette method, the potentiometric method in a ratio of $1 / 2.5 \mathrm{sol} /$ distilled water and $\mathrm{sol} / \mathrm{KCl}$, the method of Walkley and Black [14] 
and available phosphorus by extraction method of the Bray I.

The soil bulk density $D a$ was calculated as the ratio of the dry weight to the volume of the cylindrical probe.

$D a=\frac{P}{V}$ [15] with $P$. dry weight (in g) of soil sampled; $V\left(\right.$ volume in $\left.\mathrm{cm}^{3}\right)=$ $3.14 * H * r^{2} ; H=$ depth of sampling and $r=$ radius of the base of the core barrel.

Soil crusting Index was calculated according to the formula developed by [16].

$$
S C I=\left[\frac{(1.5 * F S)+(0.75 * C S)}{(C+(10 * S O M))}\right]-C t
$$

with SCI: Soil crusting Index; FS: fine silt content (\%); CS: coarse silt content (\%); $C$ : clay content (\%); SOM: Soil organic matter content (\%); $C t=$ Constant; If $\mathrm{pH}<7, C t=0$; if $\mathrm{pH}>7, C t=0.2(\mathrm{pH}-7)$.

For the interpretation of the data resulting from the calculation of the soil flapping index, the following scale will be used: $S C I>2$ : much crusted soil; $1.8<$ $S C I<2$ : crusted soil; $1.6<S C I<1.8$ : fairly crusted soil; $1.4<S C I<1.6$ : slightly crusted soil; $S C I<1.4$ : uncrusted soil.

Plant roots contained in the soil samples were recovered and weighed. The percentage of biomass root $(\mathrm{Br})$ in the soil was calculated as follows:

$R B(\%)=\frac{w_{r}}{w_{s}} * 100$ [17] with $R B=$ RootBiomass; $w_{r}=$ root weight and $w_{s}=$ soil weight.

\subsection{Data Treatment and Analysis}

The main effects tested are cropping systems, slope and their interaction. Statistical analyses were performed with SAS version 9.2 software. After verification of the conditions of normality and equality of variances, the data collected were subjected to an analysis of variance (ANOVA) following the GLM procedure. Separation of the means was performed using the Least Significant Difference (LSD) test at the $5 \%$ significance level. The variograms of the distribution of organic matter and available phosphorus were carried out with the Gs+ software. The extrapolation model used is an exponential model. The validation parameters used are the RMS (Root Mean Square), the coefficient of determination $\left(\mathrm{R}^{2}\right)$, the naguet, the nugget. The distribution maps of organic matter and available phosphorus according to the toposequence of the Kpacomey watershed have been made by ordinary kriging with the software Sufer (version 11) and ArcGIS (version 10.1).

\section{Results}

\subsection{Variation in the Physical Parameters of the Soil under Different Cropping Systems and the Slope Level}

\subsubsection{Bulk Density and Root Biomass}

Cropping systems significantly influenced bulk density $(\mathrm{p}<0.0001)$ and biomass $\operatorname{root}(\mathrm{p}<0.0001)$. However, only root biomass was significantly $(\mathrm{p}=0.0203)$ in- 
fluenced by the slope. The highest soil density $\left(1.47 \mathrm{~g} \cdot \mathrm{cm}^{-3}\right)$ was obtained with the pure Palm Grove system whilst the lowest $\left(1.38 \mathrm{~g} \cdot \mathrm{cm}^{-3}\right)$ was obtained with the Palm-Grass-Cassava system (Table 1). The Maize-Cassava and Teak Plantation cropping systems have statistically the same bulk densities. Biomass root is more abundant $(0.28 \%)$ in the soil in the Pure Palm Grove cropping system than in the other cropping systems. Taking into account the slope, the results in Table 1 show that biomass root is abundant $(0.26 \%)$ on a low slope while it is quite low $(0.14 \%)$ on a medium slope.

The interactive effect between cropping systems and slope did not influence soil bulk density $(\mathrm{p}=0.6986)$ and biomass root $(\mathrm{p}=0.3908)$. Figure 3 and Figure 4 show that on a low slope, the pure Palm grove cropping system had the highest bulk density while the lowest bulk density of the soil was obtained with the Palm grove-Cassava-maize cropping system on a high slope. The abundance of root biomass is high in the palm grove-Cassava-maize cropping system on a high slope, and lower in the Cassava-maize cropping system on a medium slope (Figure 4).

Table 1. Effect of cropping systems and slope on soil bulk density and biomass root.

\begin{tabular}{|c|c|c|c|}
\hline Studied Factors & Modalities & Bulk density $\left(\mathrm{g} \cdot \mathrm{cm}^{-3}\right)$ & $\begin{array}{c}\text { Biomass root } \\
(\%)\end{array}$ \\
\hline \multirow{4}{*}{ Cropping system } & Maize-Cassava & $1.44 \pm 0.02 \mathrm{ab}$ & $0.14 \pm 0.03 b$ \\
\hline & Pure Palm grove & $1.47 \pm 0.03 \mathrm{a}$ & $0.28 \pm 0.06 a$ \\
\hline & Palm grove-Maize-Cassava & $1.38 \pm 0.02 b$ & $0.24 \pm 0.04 \mathrm{ab}$ \\
\hline & Teak Plantation system & $1.40 \pm 0.03 \mathrm{ab}$ & $0.19 \pm 0.04 \mathrm{ab}$ \\
\hline \multirow{5}{*}{ Slope } & LSD & 0.0773 & 0.1038 \\
\hline & Low slope & $1.44 \pm 0.02 \mathrm{a}$ & $0.26 \pm 0.03 \mathrm{a}$ \\
\hline & Moderate slope & $1.40 \pm 0.02 \mathrm{a}$ & $0.14 \pm 0.02 b$ \\
\hline & High slope & $1.41 \pm 0.04 \mathrm{a}$ & $0.24 \pm 0.09 \mathrm{ab}$ \\
\hline & LSD & 0.0906 & 0.1163 \\
\hline
\end{tabular}

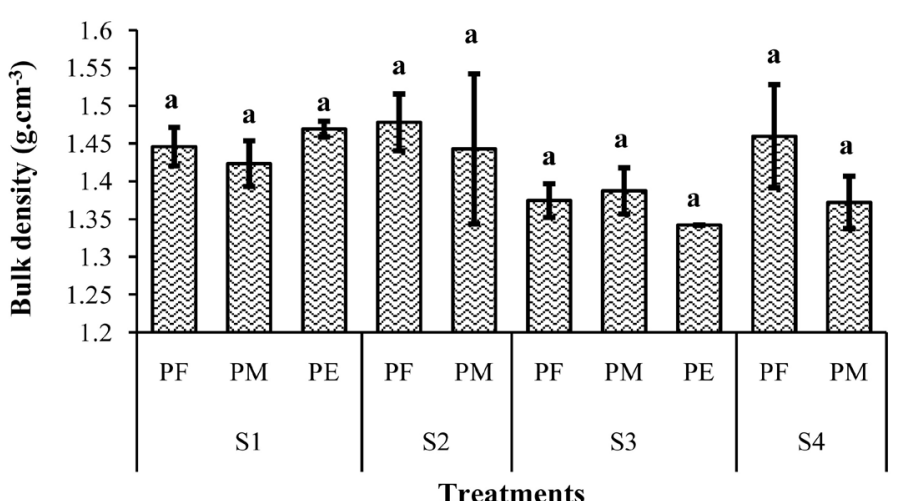

Figure 3. Combined effect of cropping systems and slope on soil bulk density. S1: Maize-Cassava; S2: Pure Palm grove; S3: Palm grove-Maize-Cassava; S4: Teak plantation; PF: Low slope; PM: Moderate slope; PE: High slope; histograms bearing the same letter are not significantly different at the $5 \%$ threshold. 


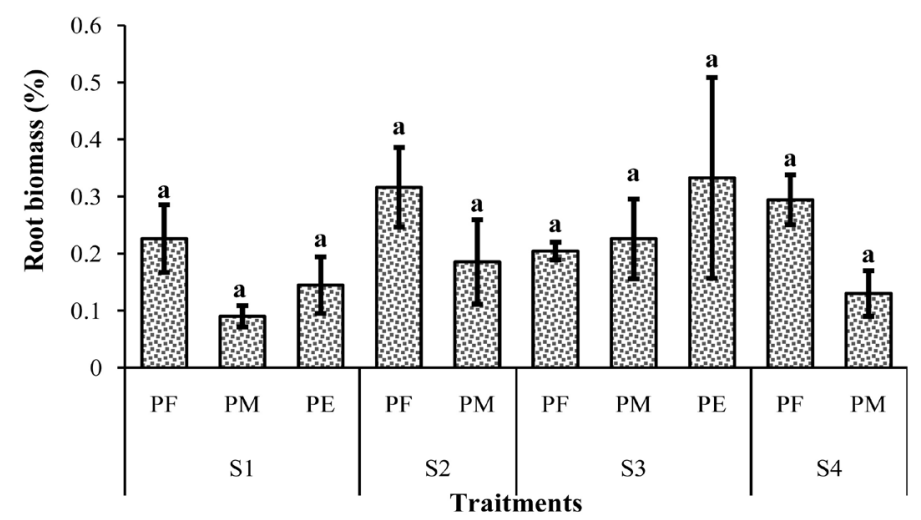

Figure 4. Combined effect of cropping systems and slope on root biomass. S1: Maize-Cassava; S2: Pure Palm grove; S3: Palm grove-Maize-Cassava; S4: Teak plantation; PF: Low slope; PM: Moderate slope; PE: High slope; histograms bearing the same letter are not significantly different at the $5 \%$ threshold.

\subsubsection{Soil Crusting Index}

Cropping systems $(\mathrm{p}=0.5814)$ and slope $(\mathrm{p}=0.9787)$ did not significantly influence soil crusting at the $5 \%$ threshold. The results in Table 2 show that the soil crusting index is higher $(0.24)$ in the pure palm grove system than in the other cropping systems. Likewise, the soil crust index is high $(0.22)$ on a moderate slope and low (0.20) on a high slope. The interaction between cropping systems and slope did not influence $(\mathrm{p}=0.2085)$ soil crusting. The analysis of Figure 5 shows that on a low slope, the pure palm grove cropping system induces an increase in the soil crusting index, contrary to a moderate slope. In addition, the Teak Plantation cropping system induces only a slight variation in the soil crusting index on a low and moderate slope.

\subsection{Variation in Soil Chemical Parameters under Different Cropping Systems and Slope Level}

\subsubsection{Soil Acidity}

Cropping systems $(\mathrm{p}=0.743 ; \mathrm{p}=0.5412)$ and slope $(\mathrm{p}=0.9597 ; \mathrm{p}=0.9624) \mathrm{did}$ not influence the actual and potential soil acidity respectively. The soil water $\mathrm{pH}$ and soil $\mathrm{pH} \mathrm{KCl}$ were high under the Palm grove-Maize-Cassava cropping system while they were low under the Maize-Cassava cropping system (Table 3). In addition, analysis of the results in Table 3 shows that there is no variation in water $\mathrm{pH}$ and $\mathrm{KCl} \mathrm{pH}$ on any of the slopes.

The interactive effect of cropping systems and slope significantly influenced current $(\mathrm{p}=0.0122)$ and potential $(\mathrm{p}=0.0345)$ soil acidity. Analysis of Figure 6 and Figure 7 shows that the Palm grove-maize-Cassava cropping system induced an increase in water $\mathrm{pH}$ and $\mathrm{KCl} \mathrm{pH}$ on a high slope. On the other hand, a reduction in water $\mathrm{pH}$ and $\mathrm{KCl} \mathrm{pH}$ was observed with the Maize-Cassava cropping system on a high slope.

\subsubsection{Soil Organic Matter and Available Phosphorus}

Cropping systems $(\mathrm{p}<0.0001)$ and slope $(\mathrm{p}=0.0463)$ significantly influenced 
Table 2. Effect of cropping systems and slope on soil crusting index.

\begin{tabular}{ccc}
\hline Studied Factors & Modalities & Soil Crusting Index (\%) \\
\hline Cropping system & Maize-Cassava & $0.19 \pm 0.01 \mathrm{a}$ \\
& Pure Palm grove & $0.24 \pm 0.05 \mathrm{a}$ \\
& Palm grove-Maize-Cassava & $0.22 \pm 0.04 \mathrm{a}$ \\
Teak Plantation system & $0.23 \pm 0.02 \mathrm{a}$ \\
LSD & 0.0848 \\
Low slope & $0.21 \pm 0.02 \mathrm{a}$ \\
& Moderate slope & $0.22 \pm 0.02 \mathrm{a}$ \\
High slope & $0.20 \pm 0.03 \mathrm{a}$ \\
LSD & 0.0971 \\
\hline
\end{tabular}

Table 3. Effect of cropping systems and slope on current and potential soil acidity.

\begin{tabular}{cccc}
\hline Studied Factors & Modalities & $\mathrm{pH}$ eau & $\mathrm{pH} \mathrm{KCl}$ \\
\hline Maize-Cassava & $5.96 \pm 0.08 \mathrm{a}$ & $5.04 \pm 0.11 \mathrm{a}$ \\
Cropping system & $6.06 \pm 0.09 \mathrm{a}$ & $5.21 \pm 0.10 \mathrm{a}$ \\
& Pure Palm grove & $6.07 \pm 0.13 \mathrm{a}$ & $5.22 \pm 0.17 \mathrm{a}$ \\
& Palm grove-Maize-Cassava & $5.97 \pm 0.06 \mathrm{a}$ & $4.99 \pm 0.10 \mathrm{a}$ \\
Teak Plantation system & $\mathbf{0 . 2 8 1 4}$ & 0.391 \\
LSD & Low slope & $6.01 \pm 0.07 \mathrm{a}$ & $5.09 \pm 0.10 \mathrm{a}$ \\
& Moderate slope & $5.98 \pm 0.05 \mathrm{a}$ & $5.09 \pm 0.07 \mathrm{a}$ \\
& High slope & $6.00 \pm 0.46 \mathrm{a}$ & $5.08 \pm 0.58 \mathrm{a}$ \\
LSD & 0.3295 & 0.4579 \\
\hline
\end{tabular}

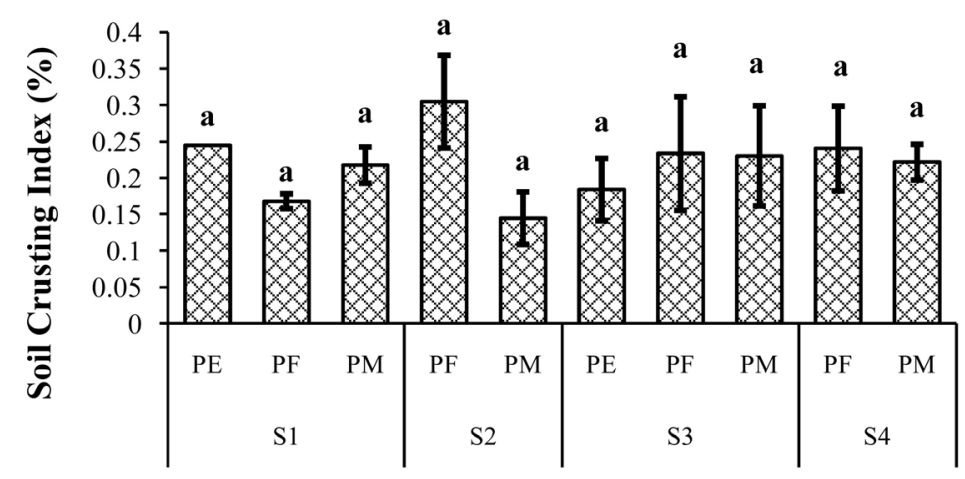

\section{Treatments}

Figure 5. Combined effect of cropping systems and slope on soil crusting index. S1: Maize-Cassava; S2: Pure Palm grove; S3: Palm grove-Maize-Cassava; S4: Teak plantation; PF: Low slope; PM: Moderate slope; PE: High slope; histograms bearing the same letter are not significantly different at the $5 \%$ threshold.

soil organic matter. Only the slope significantly $(\mathrm{p}<0.0001)$ influenced soil available phosphorus content. Looking at the cropping systems, Table 4 shows that soil organic matter content is higher (3.31\%) in the pure Palm Grove cropping 


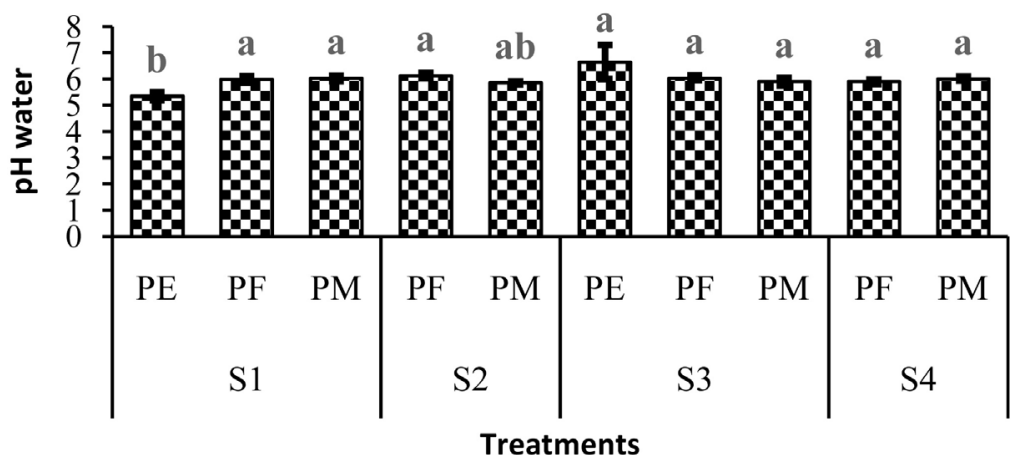

Figure 6. Combined effect of cropping systems and slope on actual soil acidity. S1: Maize-Cassava; S2: Pure Palm grove ; S3: Palm grove-Maize-Cassava; S4: Teak plantation; PF: Low slope; PM: Moderate slope; PE: High slope; histograms bearing the same letter are not significantly different at the $5 \%$ threshold.

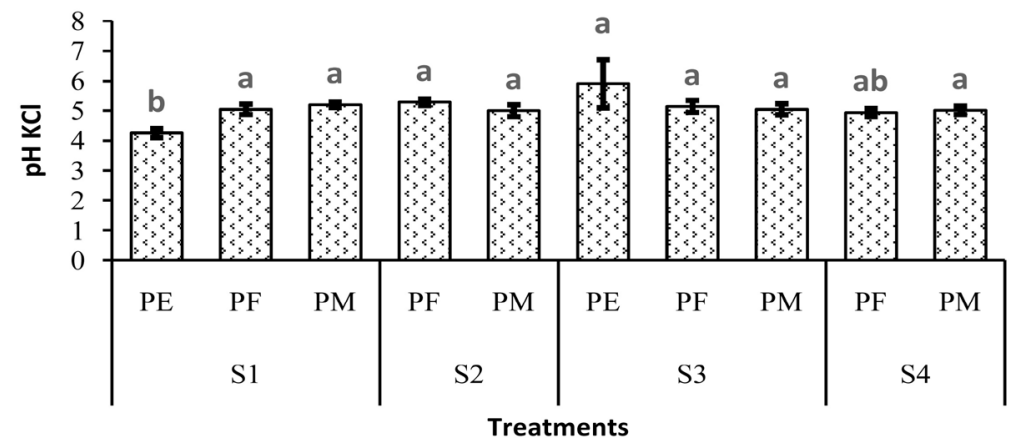

Figure 7. Combined effect of cropping systems and slope on potential soil acidity. S1: Maize-Cassava; S2: Pure Palm grove; S3: Palm grove-Maize-Cassava; S4: Teak plantation; PF: Low slope; PM: Moderate slope; PE: High slope; histograms bearing the same letter are not significantly different at the $5 \%$ threshold.

Table 4. Effect of cropping systems and slope on soil organic matter and available phosphorus in the soil.

\begin{tabular}{|c|c|c|c|}
\hline Studied Factors & Modalities & Soil Organic Matter (\%) & $\begin{array}{c}\text { Phosphore } \\
\text { available (ppm) }\end{array}$ \\
\hline \multirow{4}{*}{ Cropping system } & Maize-Cassava & $2.66 \pm 0.15 \mathrm{ab}$ & $25.08 \pm 1.39 \mathrm{a}$ \\
\hline & Pure Palm grove & $3.31 \pm 0.17 \mathrm{a}$ & $25.40 \pm 2.13 a$ \\
\hline & $\begin{array}{c}\text { Palm } \\
\text { grove-Maize-Cassava }\end{array}$ & $2.34 \pm 0.42 b$ & $21.29 \pm 4.43 \mathrm{a}$ \\
\hline & Teak Plantation system & $3.06 \pm 0.26 \mathrm{a}$ & $26.85 \pm 1.65 a$ \\
\hline \multirow{5}{*}{ Slope } & LSD & 0.6658 & 6.599 \\
\hline & Low slope & $2.90 \pm 0.15 \mathrm{a}$ & $25.39 \pm 1.37 \mathrm{ab}$ \\
\hline & Moderate slope & $2.92 \pm 0.19 a$ & $26.15 \pm 1.34 \mathrm{a}$ \\
\hline & High slope & $1.76 \pm 0.39 b$ & $19.28 \pm 4.59 b$ \\
\hline & LSD & 0.6658 & 6.3992 \\
\hline
\end{tabular}


system and low (2.34\%) in the Palm Grove-Cassava-Maize cropping system. A reduction in soil organic matter content was observed on a high slope $(1.76 \%)$ in contrast to a medium slope (2.92\%) and a low slope (2.90\%). Statistically, the available phosphorus concentration did not vary with the Cassava-Maize, pure Palm Grove, Palm Grove-Maize-Cassava and Teak plantation cropping systems. On the other hand, the slope induced variations in the concentration of available phosphorus, the highest of which was recorded on an average slope (26.15 ppm).

The interactive effect of cropping systems and slope was not significant ( $\mathrm{p}>$ 0.05 ) on soil organic matter and available phosphorus. The statistical classification shows that it is the pure palm grove cropping system on a low slope that allowed a strong increase in soil organic matter (Figure 8). On the other hand, it is the Palm Grove-Cassava-Maize cropping system that induced an increase in soil available phosphorus concentration on a low slope (Figure 9).

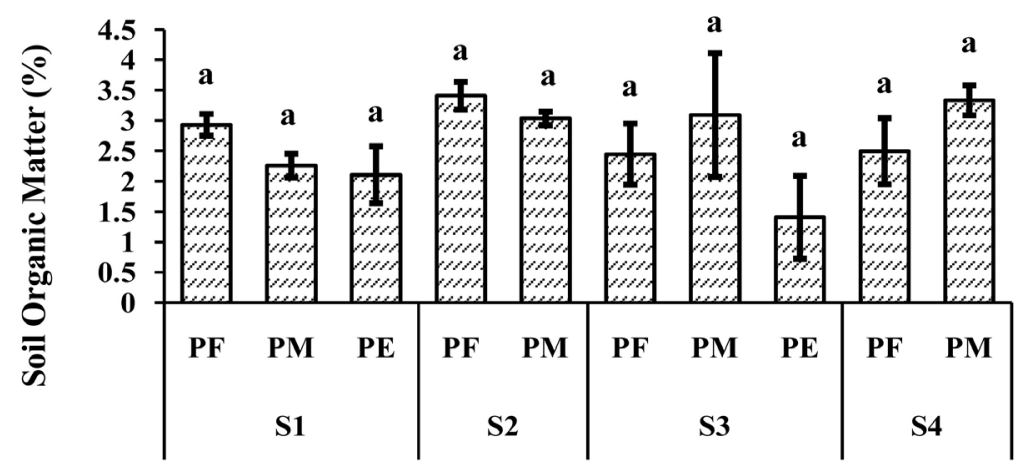

Treatments

Figure 8. Interactive effect of cropping systems and slope on soil organic matter content. S1: Maize-Cassava; S2: Pure Palm grove; S3: Palm grove-Maize-Cassava; S4: Teak plantation; PF: Low slope; PM: Moderate slope; PE: High slope; histograms bearing the same letter are not significantly different at the $5 \%$ threshold.

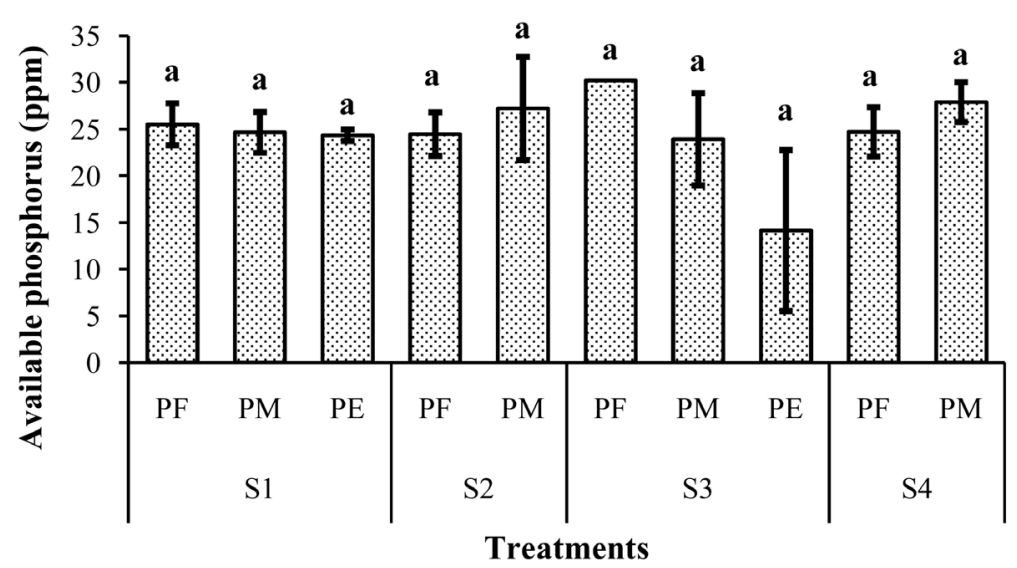

Figure 9. Interactive effect of cropping systems and slope on available phosphorus in the soil. S1: Maize-Cassava; S2: Pure Palm grove; S3: Palm grove-Maize-Cassava; S4: Teak plantation; PF: Low slope; PM: Moderate slope; PE: High slope; histograms bearing the same letter are not significantly different at the $5 \%$ threshold. 


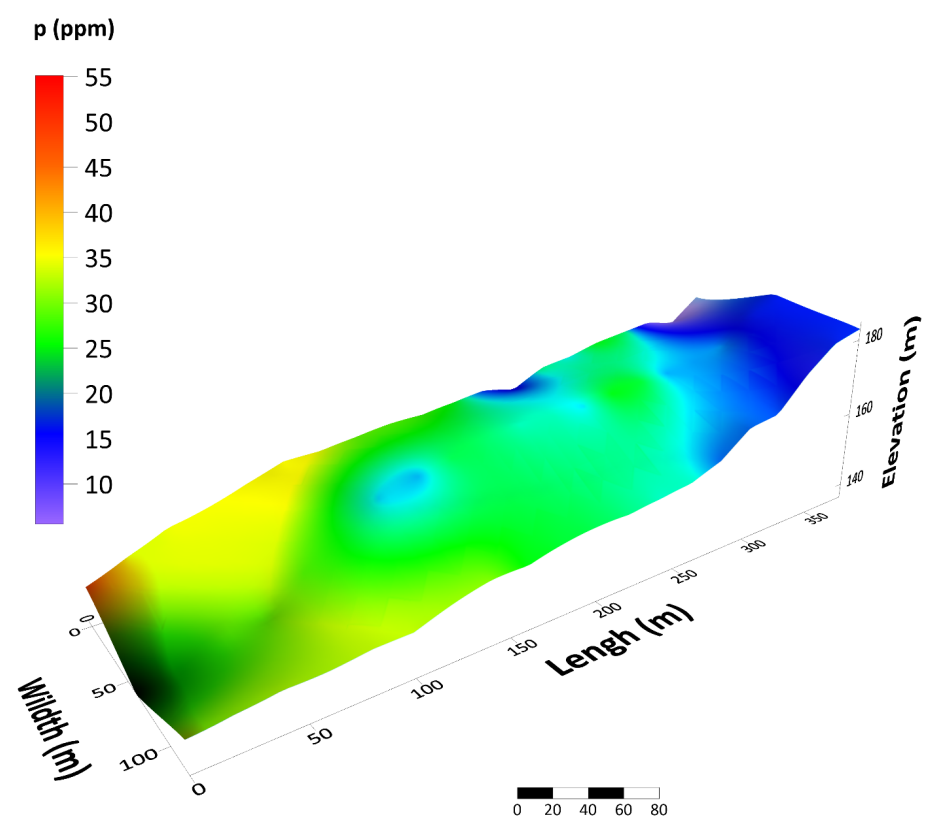

Figure 10. Distribution map of organic matter along the transects of the Kpacomey watershed.

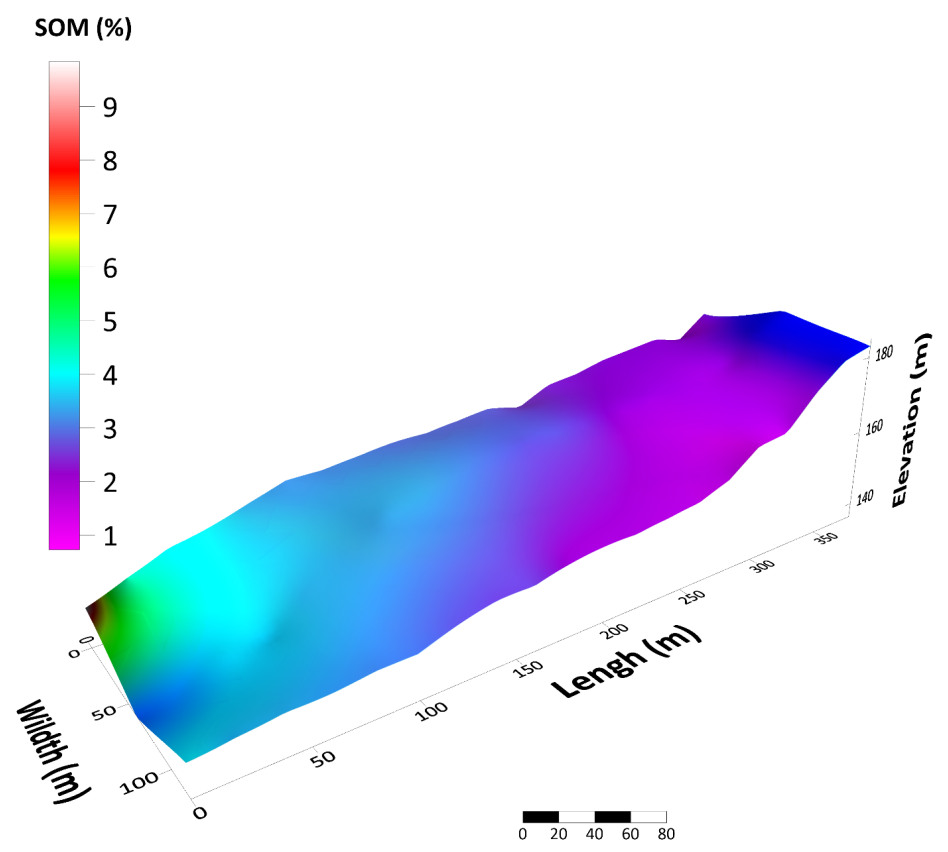

Figure 11. Distribution of available phosphorus along the transects of the Kpacomey watershed.

Figure 10 shows the distribution map of organic matter along the transects of the Kpacomey watershed. Analysis of this figure shows that soil organic matter decreases in the same direction as the slope. At the top of the slope, soil organic matter content is lowest. It is average in the middle of the slope and very high at the bottom of the slope. The distribution of soil organic matter along the transects is not uniform. Indeed, the presence of several lateral slopes at the main 
slopes at the watershed transects would explain this result. This variation in soil organic matter content along the transects shows that rainfall runoff carries with it the soil organic matter that accumulates at the bottom of the slope. The amount transported and/or redistributed varies from point to point depending on cropping systems and slope.

The distribution of available phosphorus along the transects (Figure 11) gives similar results to the distribution of organic matter. At the top of the slope, the available phosphorus concentration is less than $21 \mathrm{ppm}$. It changes from $21 \mathrm{ppm}$ in the middle of the slope to $41 \mathrm{ppm}$ at the bottom of the slope. Available phosphorus values show that the soil in the watershed is low in phosphorus available to the plant. Indeed, significant amounts of available phosphorus are transported down the Kpacomey watershed in particulate form with suspended matter or in dissolved form in runoff. Given the major role of available phosphorus, these significant losses of available phosphorus can hinder soil productivity in the Kpacomey watershed.

\section{Discussion}

\subsection{Physical Degradation}

Compaction and crusting are factors that characterize the physical degradation of soils. Apparent density is considered an indicator of low soil porosity and an indicator of soil compaction [17] [18]. The results of the present study show that the modalities of cropping systems are significantly different in terms of soil bulk density. Our results are consistent with those of [19] who showed that agricultural activities significantly influence the bulk density in the A horizon of cultivated soils. Our study showed that soil bulk density increases with the pure Palm grove cropping system as opposed to the Palm grove-Cassava maize cropping system. These results confirm the results of [20] which showed that soil bulk density values are high in the row spacing of adult palm groves whereas they are low under swaths. Other researchers observed mean bulk density values ranging from 1.4 to $1.6 \mathrm{~g} \cdot \mathrm{cm}^{-3}$ for soils under palm groves at a depth of $0-50 \mathrm{~cm}$ [21]. Thus, a high bulk density value means that voids are reduced and particles are highly compacted. The increase in bulk density values with depth indicates the progressive compacting of the soil towards depth [22].

From the point of view of root biomass, the modalities of cropping systems and slope are significantly different. The abundance of root biomass in the soil varies from one cropping system to another and it remains higher with the pure palm grove cropping system. This abundance is due to the density and root system of oil palm cultivation. Soils can have a shallow compacted horizon, which limits the rooting of plants and thus restricts their supply of water and mineral elements [23].

Structural disaggregation is at the origin of the formation of crustal crust and erodibility must therefore be a direct function of structural stability, the measurement of which gives a precise indication of the dimensional distribution of the fragments [24]. These authors have shown that there is a relationship be- 
tween this sensitivity of soils to disintegration and flapping, but this relationship is complex, multifaceted and probably difficult to put into equation. The results of our study showed that the soils of the watershed of Kpacomey are not flapping under the effect of cropping systems and slope according to the interpretation grid proposed by [16] Rémy Marin-Laflèche]. This confirms the results of [24] who stated that the measurement of structural stability is not then a good indicator of soil degradation, because in some cases of heavy rainfall, runoff can occur even without the formation of flapping crusts and large aggregates or fragments can be transported.

\subsection{Chemical Degradation}

Our results show that the interactive effect of cropping systems and slope significantly affects soil water $\mathrm{pH}$ and soil $\mathrm{KCl} \mathrm{pH}$, and an increase in these two types of acidity is induced by the Palm grove-Cassava maize cropping system on a high slope. According to the interpretation grid proposed by [25], the soil of the Kpacomey watershed is weakly acidic under the pure Palm grove-Cassava, Palm grove-Maize-Cassava and Teak plantation cropping systems. Soil acidity is an indication of the equivalent chemical elements at soil level in general and is directly related to exchangeable cations and anions [19]. The rate of acidification varies greatly depending on soil type, land use, productivity and management of the farming system [26].

Soil organic matter, because of its close relationship with fertility, is one of the important factors in controlling sustainable plant productivity [27]. Indeed, through its degradation and mineralization, soil organic matter improves the physical and chemical quality of soils and provides the nutrients necessary for crop development [28]. Available phosphorus mainly associated with soil practice is found in runoff to the river and soil levels of available phosphorus are strongly accumulated in the first five centimeters of soil and decrease with depth [29]. Analyses from our results show that cropping systems significantly influence soil organic matter content. Indeed, for the cropping system modalities, a higher level of organic matter was found in the pure Palm Grove cropping system than in the Palm Grove-Cassava maize cropping system. These results are consistent with those of [22] who proved that this variability in organic matter content is due to the ridge management of food crops associated with the young planting age and the row planting method and the swathing of plant matter resulting from palm pruning. Our results can be explained by the fact that nutrient loss by runoff is strongly related to cropping systems in agricultural watersheds. Moreover, organic matter is either transported by surface runoff or as individual particles or adsorbed to mineral particles in the soil [17]. The results of our studies thus explain the deficit of the watershed soils in available phosphorus and organic matter.

\section{Conclusion}

The main objective of the present study was to assess the influence of cropping 
system and slope on the physical and chemical degradation soil. Then, root biomass, soil bulk density and soil crusting index were studied as soil physical parameters while soil organic matter and available phosphorus contents and $\mathrm{pH}$ ( $\mathrm{pH}$ water and $\mathrm{pH} \mathrm{KCl}$ ) were assessed as chemical parameters. Results showed that cropping systems significantly influenced root biomass and soil bulk density. The soil is compact under the pure Palm grove cropping system contrary to the Palm grove-Cassava maize cultivation system. The root biomass was significantly influenced by the slope and is higher with the pure Palm grove cropping system. Also, it is high on a low slope while it is quite low on a medium slope. Cultivation systems and slope did not influence the soil threshing at the watershed level. Furthermore, combined effect of crop systems and slope did not influence soil acidity. At the watershed level, the soil is acidic under all cropping systems. In addition, organic matter was significantly influenced by cropping systems. Soil organic matter content was higher in the pure Palm grove cropping system and lower on a high slope. Available phosphorus concentration did not vary with the cropping systems. The slope induced variations in available phosphorus concentration with the highest concentration recorded on a medium slope. These results indicate that soil degradation is influenced by cropping systems and slope.

\section{Conflicts of Interest}

The authors declare no conflicts of interest regarding the publication of this paper.

\section{References}

[1] Food and Agriculture Organization (2007) La Situation Mondiale de l'Alimentation et l'Agriculture. Agriculture No. 38, Organisation des Nations Unis Pour l'Alimentation et l'Agriculture, Rome, 256.

[2] Food and Agriculture Organization (2015) Les sols sont une Ressource Non Renouvelable. Organisation des Nations Unies pour l'Alimentation et l'Agriculture, Rome, 4.

[3] Food and Agriculture Organization (2012) La Situation Mondiale de l'Alimentation et de l'Agriculture: Investir dans l'Agriculture pour un Avenir Meilleur. Organisation des Nations Unis Pour l'Alimentation et l'Agriculture, Rome, 202.

[4] Egah, J., Baco, M.N., Lokossou, R.S., Moutouama, F.T., Akponikpè, P.B.I., Fatondji, D., Djènontin, A.J., Tossou, C.R. and Sokpon, N. (2014) Incidence économique des Techniques exogènes de Conservation de l'eau et des sols au Bénin. Bulletin de la Recherche Agronomique du Bénin, 75, 28.

[5] Penot, E., Domas, R., Fabre, J., Poletti, S., Mac, D.C., Dugué, P. and Le Gal, P.-Y. (2015) Le Technicien Propose, le Paysan Dispose. Le cas de L'Adoption des Systèmes de Culture sous Couverture Végétale au lac Alaotra, Madagascar. Cahiers Agricultures, 24, 84-92. https://doi.org/10.1684/agr.2015.0745

[6] Benbrahim, K.F., Ismaili, M., Benbrahim, S.F. and Tribak, A. (2004) Problèmes de Dégradation de l'Environnement par la Désertification et la Déforestation: Impact du Phénomène au Maroc. Science et Changements Planétaires/Sécheresse, 15, 307-320. 
[7] Toko, I. and Sinsin, B. (2008) Les Phenomènes d'érosion et d'Effondrement Naturels des sols (Dongas) du Parc National du W et leur Impact sur la Productivité des Pâturages. Science et Changements Planétaires/ Sécheresse, 19, 193-200.

[8] Somé, D., Zombré, P.N., Zombré, G. and Macauley, H.R. (2004) Impact de la Technique du zaï sur la Production du niébé et sur l'évolution des Caractéristiques Chimiques des sols très Dégradés (Zipellés) du Burkina Faso. Science et Changements Planétaires/ Sécheresse, 15, 263-269.

[9] Kouelo, A.F., Houngnandan, P., Azontonde, H.A., Benlansour, M., Rabesiranana, N. and Mabit, L. (2015) Assessment of the Level of Soil Degradation in Three Watersheds Affected by Intensive Farming Practices in Benin. Journal of Experimental Biology and Agricultural Sciences, 3, 529-540.

[10] Akplo, T.M., Kouelo, A.F., Houngnandan, P., Azontonde, H.A., Agonvinon, M.S. and Bokossa, T.S. (2019) Factors Influencing Soil Erosion Control Practices Adoption in Centre of the Republic of Benin: Use of Multinomial Logistic. Journal of Agricultural Science, 11, 110-122. https://doi.org/10.5539/jas.v11n17p110

[11] Adégbidi, A. and Biaou, G. (1995) L'Agriculture Durable au Bénin: Rôle de l'Etat. A la Recherche de l'Agriculture Durable au Bénin. Instituut voor Sociale Geografie, Amsterdam, 160.

[12] Akplo, T.M. (2020) Evaluation de l'Efficacité des Pratiques de Lutte Contre l'érosion Hydrique du sol et Leur Influence sur la Productivité du maïs dans le Bassin Versant du Zou, Bénin. Université d'Abomey-Calavi, Bénin, 231 p.

[13] Igue, A.M., Agossou, V. and Ogouvidé, D.T. (2008) Influence des Systèmes D’Exploitation Agricole sur L'intensité de la Dégradation des Terres dans le Département des Collines au Bénin. Bulletin de la Recherche Agronomique du Bénin, 61, 39-51.

[14] Walkley, A. and Black, I.A. (1934) An Examination of the Degtjareff Method for Determining Soil Organic Matter and a Proposed Chromic Acid Titration Method. Soil Science, 37, 29-38. https://doi.org/10.1097/00010694-193401000-00003

[15] Okalebo, J.R., Gathua, K.W. and Woomer, P.L. (2002) Laboratory Methods of Soil and Plant Analysis: A Working Manual, 2nd Edition. The Sustainable Agriculture Centre for Research Extension and Development in Africa, Bungoma and Nairobi, 128.

[16] Rémy, J.C. and Marin-Laflèche, A. (1976) L'entretien Organique des Terres. Coût d'une Politique de l'Humus. Entreprises Agricoles, 84, 3-7.

[17] Kouelo, A. (2016) Effets des Pratiques Culturales sur la Dégradation du sol au niveau des trois bassins Versants du sud Bénin. Universités d'Abomey-Calavi, Bénin, 230.

[18] Akplo, T.M., Kouelo, A.F., Ahogle, A.A.M., Houngnandan, P., Azontonde, H.A., Benmansour, M., Rabesiranana, N., Fulajtar, E., Hounkonnou, G.J.J. and Klotoe, M.-A.D. (2020) Influence of Soil Conservation Practices on Soil Moisture and Maize Crop (Zea mays L.) Productivity in Centre Benin. African Journal of Plant Science, 14, 8-23. https://doi.org/10.5897/AJPS2019.1927

[19] Brady, N.C. and Weil, R. (2008) The Nature and Properties of Soils. 14th Edition. Pearson-Prentice Hall, Upper Saddle River, 990.

[20] Aholoukpè, H.N.S., Amadji, G.L., Blavet, D., Chotte, J.L., Deleporte, P., Dubos, B., Flori, A. and Jourdan, C. (2016) Effet de la Gestion des Feuilles d'élagage du Palmier à huile sur le Stock de Carbone et les Propriétés Physico-Chimiques du sol dans les Palmeraies Villageoises du Bénin. Biotechnology, Agronomy, Society and Environment, 20, 171-182. 
[21] Nodichao, L., Ake, S. and Jourdan, C. (2008) Development du Systeme Racinaire chez le Palmier a Huile Selon L'origine Genetique et le Regime Hydropotassique du sol. Agronomie Africaine, 20, 277-289. https://doi.org/10.4314/aga.v20i3.46264

[22] Djègui, N., de Boissezon, P. and Gavinelli, E. (1992) Statut Organique d'un sol Ferrallitique du Sud Bénin sous forêt et Différents Systèmes de Cultures. Cahier Orstom, Série Pédologique, 17, 5-22.

[23] Alongo, S., Visser, M., Drouet, T., Kombele, F., Colinet, G. and Btogaer, J. (2013) Effets de la Fragmentation des forêts par l'Agriculture Itinerante sur la Dégradation de Quelques Propriétés Physiques d'un Ferralsol échantillonné à Yangambi, R.D. Congo. Tropicultura, 31, 36-43.

[24] Le Bissonnais, Y. and Le Souder, C. (1995) Mesurer la Stabilité Structurale des sols Pour évaluer leur Sensibilité à la Battance et à l'érosion. Etude et Gestion des Sols, 2, 43-56.

[25] Baize, D., King, D. and Jamagne, M. (2001) The 'Référentiel Pédologique': A Sound Reference Base for Soil: A Tool for Soil Designation. European Soil Bureau-Research Report, 7, 85-92.

[26] Moore, G. (2001) Soil Guide: A Handbook for Understanding and Managing Agricultural Soils. The National Library of Australia, Canberra, 4343, 388.

[27] Razafimbelo, T.M., Albrecht, A., Basile, I., Borschneck, D., Bourgeon, G., Feller, C., Ferrer, H., Michellon, R., Moussa, N., Muller, B., Oliver, R., Razanamparany, C., Seguy, L. and Swarc, M. (2006) Effet de Différents Systèmes de Culture à Couverture végétale sur le Stockage du Carbone dans un sol Argileux des Hautes Terres de Madagascar. Etude et Gestion des Sols, 13, 113-127.

[28] Arrouays, D., Balesdent, J., Germon, J.C., Jayet, P.A., Soussana, J.F. and Stengel, P. (2002) Contribution à la Lutte Contre l'Effet de Serre. Stocker du Carbone dans les sols Agricoles de France? Expertise Scientifique Collective. Synthèse du Rapport. National Institute of Agricultural Research, Paris, 32.

[29] Djossou, J.M., Kooke, X.G., Hountondji, M.O., Imorou, I.T. and Djego, J.G. (2019) Influence des Plantations de Tectona Grandis et de Acacia Auriculiformis de Différents âges des forêts Classées de Djigbé et de Ouèdo sur le sol Ferralitique au Sud du Bénin. International Journal of Innovation and Applied Studies, 25, 924-933. 